\title{
ST-Elevation Myocardial Infarction in Duchenne Muscular Dystrophy
}

\author{
LUCIANA TEODORA ROTARU1, MARIA FORTOFOIU1, ADRIAN MITA², ANCA BARAU ABU ALHIJ A2, OANA CRICIOTOIU,, \\ VERONICA CALBOREAN ${ }^{4}$, CRISTINA GEORMANEANU ${ }^{1}$, LIVIU MARTIN ${ }^{5}$, MIHAI BANICIOIU ${ }^{1}$, LAVINIA MARIA GHEORMAN ${ }^{6}$, \\ MIRCEA-CATALIN FORTOFOIU2 \\ 'University of Medicine and Pharmacy of Craiova, Department of Emergency Medicine and First Aid, 2-4 Petru Rares Str.,200349, \\ Craiova, Romania \\ ${ }^{2}$ University of Medicine and Pharmacy of Craiova, Department of Internal Medicine, 2-4 Petru Rares Str., 200349, Craiova, \\ Romania. \\ ${ }^{3}$ University of Medicine and Pharmacy of Craiova, Neurology Department, 2 Petru Rares Str., 200349, Craiova, Romania \\ ${ }^{4}$ University of Medicine and Pharmacy of Craiova, Cardiology Department, 2 Petru Rares Str., 200349, Craiova, Romania \\ ${ }_{5}^{5}$ Military Emergency Hospital Dr. Stefan Odobleja, Surgery Department, 150 Caracal Str., 200749, Craiova, Romania \\ ${ }_{6}^{6}$ Military Emergency Hospital Dr. Stefan Odobleja, Department of Diabetes \& Metabolism, 150 Caracal Str., 200749, Craiova, \\ Romania
}

The papaer presents the cases of a twelve years old boy brought in emergency department with the following symptoms: pain in the thorax and upper abdomen, nausea, vomiting with sudden onest $11 \mathrm{~h}$ ago.

Keywords: Duchenne muscular dystrophy, ST-elevation myocardial infarction

In Duchenne muscular dystrophy (DMD), the electrocardiogram (ECG) is abnormal at very early stages, before echocardiographic findings of cardiomyopathy or evidence of myocardial fibrosis (MF) on cardiac magnetic resonance (CMR). The appearance of ST elevation myocardial infarction (STEMI) are an exceptional event in DMD even in DMD-associated cardiomyopathy.

\section{Experimental part}

A 12-year old boy with confirmed DMD; without positive family history for this disease or personal history of cardiac diseases; under treatment with $\beta$-blockers and corticosteroids; is brought in emergency department (ED) for the following symptoms: pain in the thorax and upper abdomen, nausea, vomiting with sudden onset $11 \mathrm{~h}$ ago.

The electrocardiogram (ECG) and aspect of genetic analysis are illustrated in the figures below (fig. 1, 2).

Troponin I (cTnl) initial level was $3000 \mathrm{ng} / \mathrm{mL}$ and increasing up to $20000 \mathrm{ng} / \mathrm{mL}$; N-terminal pro-B-type natriuretic peptide (NT-pro BNP) was $1799 \mathrm{pg} / \mathrm{mL}$.

Echocardiography showed hypokinesia of posteroinferior wall and basal septum and left ventricular ejection fraction (LVEF) $<35 \%$. Coronarography was normal. CMR with gadolinium has revealed MF in inferolateral wall.

The therapeutic decision was initially resorted to subcutaneous heparin administration, subsequently suppressed; adding enzyme conversion inhibitors (perindopril); doubling the corticosteroid dose to $60 \mathrm{mg} /$ day and emergency air evacuation to hospital with the pediatric cardiology clinic. Administration of $\beta$-blockers was suppressed due downward trend of the LVEF.

\section{Results and discussions}

This case has some peculiarities: child with confirmed DMD cardiomyopathy under treatment, without personal history of ventricular dysfunction (VD) or arrhythmias with elements for STEMI sustained by those described above.

Starting from these prerequisites, several issues are raised related to the interpretation of clinical and biological signs, explaining the determinism of the phenomenon, differentiating aspects related to myocardial injury, the usefulness of current guidelines[1-6].

In this case, the most probable hypothesis can be accelerated apoptosis associated with maldistribution and the consecutive decrease of LVEF well supported by the stage of DMD, patient age and CMR aspects. Very rarely an acute myocardial infarction (MI) is a DMD-related cardiac event but is likely that is not caused by coronary artery disease and apoptosis is usually painless [7-10]. Previous arrhythmias was not documented and effects of long-term corticosteroid therapy or presence of vasculitis have not been confirmed by coronarography.

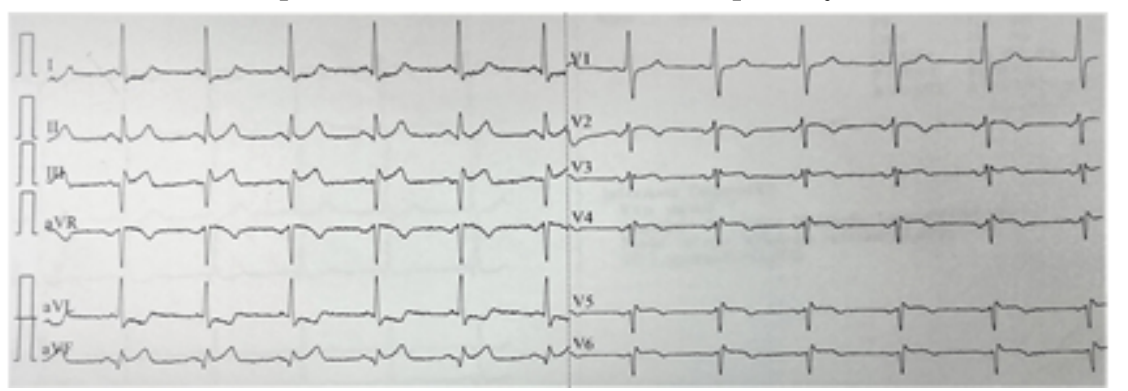

Fig. 1. The ECG revealed the acute inferior myocardial infarction (ST-segment elevation in leads III and aVF)

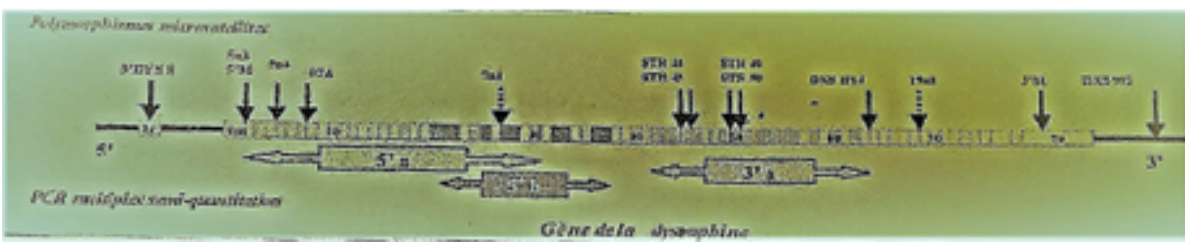

Fig. 2. Genetic analysis features.

*email: catalin1972@hotmail.com; Phone +40722320438 
Chest pain is the most common clinical manifestation in DMD and is usually considered to be caused by skeletal muscle damage but many of the symptoms that belong to DMD are present in heart failure [11-17].

CTnl and BNPs are serum biomarkers for ischemic coronary artery disease and there are no routine tests in patients with DMD [2]

The most common ECG findings in patients with DMD are left or right ventricular hypertrophy and sinus tachycardia. Q waves in the left precordial leads, right bundle branch block, tall R waves and increased R/S amplitude in lead V1, right axis deviation are another ECG findings. Atrial fibrillation and atrial flutter, can also occur. When LVEF $<35 \%$, may occur ventricular tachycardia, premature ventricular complexes and conduction abnormalities[11-14].

Sudden cardiac death occur occasionally when LVEF $>35 \%$ and VD is predictive for rhythm arrhythmias [18-21].

In clinical guidelines, evaluations for cardiomyopathy are well established but for symptomatic patients with demonstrated cardiac disease assessment will be made whenever the cardiologist considers necessary[1, 22-25]

Current guidelines do not provide any recommendation on thrombolytic therapy in children and doesn't stipulate clearly the placement of implantable cardioverterdefibrillators in DMD- associated cardiomyopathy [1-2].

\section{Conclusions}

Acute chest pain in DMD patient requires, a detailed cardiac history, ECG, CTnl and reference to the cardiologist. The clinical features of VD and evidence of MF on CMR inflict Holter monitoring. Current guidelines are not ready for DMD-associated STEMI at children.

\section{References}

1.HOR, KAN, N. et al. Neuromuscular Disorders; 2018; 28(9):711-716. 2.HOR, K.N., JOHNSTON, P., KINNETT, K., MAH, M.L., STIVER, C., MARKHAM, L., et al. J Neuromuscul Dis 2017;4(4):307-14

3.CALBOREAN, V., MISCOCI, S. A., ISTRATOAIE, O., GALCEAVA, O.,ALEXANDRU, D.O., GUTA, M.M., GHEORMAN, V., PADUREANU,V., FORTOFOIU, C.M., DIJ MARESCU, A.L., GHEONEA, D.I. Rev. Chim. (Bucharest), 69, no 6, 2018, p. 1527-1532.

4.VLADU,I.M., RADU,L., GIRGAVU ,S.R., TENEA COJAN, T.S., ENE,C.G., CALBOREAN , V., GHEORMAN ,V., CLENCIU,D. Rev Chim (Bucharest), 69,no 9, 2018, p.2479-2481.

5.CORICI, O. A., TANASIE, C.A., ALEXANDRU, D.O., FLORESCU, C.M,COMANESCU, M.V., KAMAL, C., TENEA-COJAN, T.S, IANCAU, M.,DINESCU, S.N. Rom J MorpholEmbryol;2018,59(1):93-103.

6.BALEANU, V.D., CONSTANTIN, D.V., PASCAL,A., ALEXANDRU, D.O., BOBIC,S., SOCEA,B., MANDA,A.L., DAVITOIU, D., DIJ MARESCU,A.L., GEORGESCU, I., MIREA, C.S., Rev Chim (Bucharest), 69, no 7, 2018, p 1740-1743.

7.CALBOREAN, V., GHEORMAN, V., OCTAVIAN, I., MUSTAFA, R.E.,COJ OCARU, P.A., ALEXANDRU, D.O., GALCEAVA, O., MITA, A., MISCOCI, S.A., AL NAMAT, R., GHEONEA,D.I. Rev. Chim. (Bucharest), 69, no. 5, 2018, p.1134-1138.
8.PUIU,I., ALBU, C.V., TARTEA, E.A., CALBOREAN,V., GHEORMAN,V., DINESCU, S.N., VASILE,R.C., DINESCU, V.C., BICA, E.C., ROMANESCU, F.M., TUDORASCU,D.R. Rev Chim (Bucharest), 69, no 10, 2018, p. 2744-2748.

9.NOVAC, M.V., NICULESCU, M., MANOLEA, M.M., DIJ MARESCU, A.L., ILIESCU,D.G.,NOVAC,M.B., ROTARU,L.T, STOENESCU, M.F., TABACU, M.C., TUDORACHE,S., BUSUIOC, C.J ., GHEONEA, I.A.Rom J Morphol Embryol , 2018, vol 59, p. 715-720.

10.SIMINEL, M.A., GHEONEA, C., STANESCU, M.R., COMANESCU, A.C.,DIJ MARESCU, A.L., NEAMTU, S.D., COTOI, B.V., NEDELCUTA, R.M., NICULESCU, E.C.Rom J Morphol Embryol , 2015, vol 56, 301308.

11.KAMDAR, FORUM; GARRY, DANIEL, J. J ournal of the American College of Cardiology; 2016; 67(21):2533-46.

12.VILLA ,C.R., CZOSEK, R.J., AHMED, H., KHOURY, P.R., ANDERSON, J.B., KNILANS, T.K., et al. J Am Heart Assoc 2015;5(1) Dec 31.

13.BIRNKRANT, D.J., BUSHBY, K., BANN, C.M., ALMAN, B.A., APKON, S.D., BLACK-WELL, A., et al. Lancet Neurol 2018;17(4):347-61 Apr. doi: 10.1016/ S1474- 4422(18)30025- 5.

14.BARDY, G.H., LEE, K.L., MARK, D.B., POOLE, J.E., PACKER, D.L , BOINEAU, R. , et al. N Engl J Med 2005;352(3):225-37.

15.GHEORMAN,V., MILITARU,F., CALBOREAN,V., GHEORMAN, L.M., CHIRITA, A.L., MITA, A., GALCEAVA, O., GHEORMAN, V., STANCA, D., UDRISTOIU, I. Rev Chim.(Bucharest), 69, no. 4, 2018, p.881-885.

16.CALBOREAN, V., CIOBANU, D., MIREA, S.C., GALCEAVA, O., GHEORMAN, V., PADUREANU, V., FORTOFOIU, C.M., FORTOFOIU, M., MITA, A., DINESCU, S.N., MISCOCI, S.A., DINESCU, V.C. Rev. Chim. (Bucharest), 69, no. 9, 2018, p.2461-2464

17.FORTOFOIU, M., FORTOFOIU, M.C., COMANESCU, V., DOBRINESCU, A.C., PÃDUREANU, V., VERE, C.C., STREBA, C.T., CIUREA, P.L. Rom J Morphol Embryol. 2015;56(4):1461-5.

18.ENE,C.G.,ROSU,A., GHEORMAN,V., CALBOREAN,V., TENEA COJAN,T.S., ROGOVEANU,O.C., VLADU,M.I., RADU, L. Rev Chim (Bucharest), 69, no 7, 2018, p.1851-1854.

19.GHEORMAN,V., CHIRITA,A.L., DUMITRESCU,E.M., ROGOVEANU,I., ISTRATOAIE,O., GHEORMAN,V.,PANA,R.C. Rom J Morphol Embryol 2016, 57(1): 45-50.

20.TRASCA, S.P., FLORESCU, C., DINESCU, V.C.,PUIU, I., DINESCU, S.N., TUDORASCU, D.R., BICA, C., VASILE, R.C., ROMANESCU, F.M., BUNESCU, M.G., CIOATERA, N., GOANTA, E.V. Rev Chim (Bucharest), 2018, 69, nr.12, p.3600-3604.

21.BUICU, G.E., GRECU, M.G., SALCUDEAN, A., GRECU, I.G., MARINESCU, C., NIRESTEAN, A., TURLIUC, S., HADAREANU, V., UDRISTOIU, I. EUROPEAN PSYCHIATRY, 41, 2017, p S583-S584.

22.CALBOREAN, V., GHEORMAN, V.,CONSTANTIN, C. ISTRATOAIE, 0. J ournal of Cardiovascular Emergencies, 2018, 4, nr.2, p. 101-105.

23.CHIMORGIACHIS,A.,CONSTANTIN,M.D.G.,UDRISTOIU,T., PIRLOG, M.C.,UDRISOIU,I. JOURNAL OF NEURAL TRANSMISSION, 114, issue 7, 2007, p. CXX-CXX.

24.CALBOREAN,V., GHEORMAN,V., AL NAMAT, R., CAZACU,I. M., VARJU,P., GEDE, N., STREBA,T.C., VERE, C.C., GHEONEA,D.I., GHEORMAN, V., LUNGULESCU, C., LUNGULESCU, C.,V. Rev Chim (Bucharest), 68, no 12, 2017, p.3010-3014

25.STOENESCU,V..E., NICULESCU, M., NOVAC, L., MANOLEA, M.M., TOMESCU, P.I., DIJ MARESCU, A.L., NOVAC,M.B., TUDORACHE, S., ILIESCU, D.G . Rom J Morphol Embryol , 2017, vol 58, 791-800.

Manuscript received: 19.07 .2018 